\title{
Ladders in the orchard
}

\section{What's next for OER?}

A

movement to encourage and increase the creation and use of open educational resources (OER) in U.S. higher education has been growing for about 20 years. ${ }^{1}$ In Massachusetts, for example, 71 percent of public colleges are already using OER to some extent, although the total number of courses affected remains relatively small. The most common number of OER courses per school is between 11 and $20 .^{2}$ Studies continue to show that the high cost of textbooks is a burden for students, to the point that many states have adopted legislation to reduce textbook costs or promote OER. ${ }^{3}$ However, in a study that surveyed faculty from the Virginia Community College System, Dr Braddlee and Amy VanScoy concluded that use of OER is still a "niche phenomenon, the province of innovators and early adopters." ${ }^{4}$ Any change, no matter how potentially beneficial, takes both time and effort.

Multiple studies have shown that vetted OER support learning as effectively as traditional textbooks, ${ }^{5}$ although Phillip J. Grimaldi et al. have suggested that standard research methods are unlikely to correctly measure the learning benefits of OER. ${ }^{6}$ Assuming faculty are unlikely to choose OER of lower quality than traditional resources, arguments for adopting OER include affordability and equity, flexibility, and easy digital access.

\section{OER at STCC}

Springfield Technical Community College (STCC) in western Massachusetts enrolls approximately 5,000 students. The majority (54\%) receive Pell Grants. ${ }^{7}$ STCC launched an OER initiative in 2014 because the library recognized a severe need for lower-cost textbooks. In 2017, the OER committee developed strategic goals and objectives for the initiative. One goal was to increase "the "number of students impacted from 536 per year to approximately 1,400 per year, and create a yearly savings of approximately $\$ 140,000$ " within three years. ${ }^{8}$ In spring 2020 , there were 52 zero textbook cost (ZTC) courses offered at STCC, impacting 2,332 students per year and saving them an estimated $\$ 332,254.88$ per year.

To encourage the use of OER at STCC, the outreach and OER librarian has presented at faculty development days, tabled alongside publishers during textbook fairs, promoted ZTC courses to advisors, created promotional materials, and sent regular emails to the campus community. She also searched for funding opportunities, which paid off when STCC won a grant from the National Network of Libraries of Medicine (NNLM) in April 2018 to fund a faculty OER fellowship program (this money was matched by funds from a Title III grant). Thanks to the fellowship program, 12 new OER courses were planned for fall 2020, increasing the total estimated annual savings by $\$ 127,209.15$ and the number of students affected annually by 793 .

\section{Student survey results}

In fall 2019, the STCC Library asked students to participate in a survey about how the cost of

Chelsea Contrada is outreach and OER librarian at Springfield Technical Community College, email: cacontrada@stcc.edu and Kathryn Good-Schiff is reference and local history librarian at the Westfield Athenaeum, email: kgoodschiff@westath.org

(O) 2021 Chelsea Contrada and Kathryn Good-Schiff 
course materials impacts their lives. More than 1,000 students participated. Our objectives were to confirm the importance of textbook affordability, while also gathering information to further promote OER. The survey findings point to the following reasons for transitioning courses to be ZTC by adopting OER.

1. The cost of course materials is a significant burden for students. The survey found that in 20192020, STCC students would spend an average of $\$ 716-\$ 1,352$ on textbooks. This is significant relative to tuition and fees ( $\$ 5,054$ was the full-time, in-state cost for fall 2019). Students said they weigh the cost of textbooks against necessities like groceries and transportation, and some expressed anger or frustration at single textbooks costing hundreds of dollars. Using OER would eliminate this cost barrier, leading to a more equitable educational experience. ${ }^{10}$

2. Students decide not to buy course materials due to high costs, despite worries about academic success. A majority (58\%) said they have decided against buying a required textbook at some point. Nearly all who declined to buy a book due to high cost (95\%) were concerned this would hurt their grade. As Grimaldi and his coauthors and others write, a measure of the true value of OER is that they allow students who would not be able to access a textbook for financial reasons to do so. ${ }^{11}$ With OER, the cost to students is low or zero, although it is important to note that, as both Lindsey Gumb and Hong Lin note, a good Internet connection is a prerequisite for OER access. ${ }^{12}$

3. Most students have purchased required texts they later felt were unnecessary. Nearly two-thirds (62\%) said they have spent money on a textbook they came to feel they did not need. Often this was because only a small portion of the book was assigned. OER, on the other hand, can be easily excerpted or otherwise tailored to an individual course syllabus. ${ }^{13}$

4. The cost of textbooks influences which and how many courses students take. About two-thirds (65\%) said the cost of textbooks influences which and how many courses they take. One student stated, "I will switch my schedule around so I take one class with the expensive book and another with a less expensive book." This is consistent with a study by the Florida Virtual Campus that found taking fewer courses or skipping certain courses is a way for students to miti- gate the high cost of course materials. ${ }^{14}$ In contrast, Rebecca Griffiths and others found that "students who took multiple OER courses on average earned more college credits over time than otherwise similar students who took no OER courses." ${ }^{15}$

5. Most students would prefer a course with free online materials. A majority (65\%) said they would choose a course with free online materials over a course using traditional materials. Students prefer OER for multiple reasons, including flexibility and cost. One student in an OER course said, "Our professor lets us use a free online book that I am beyond grateful for." Penny Beile and others also found that students in a history course "were grateful for day-one access to no-cost course materials."

\section{Reaching higher, together}

At this point, STCC's OER initiative has gotten most of the "low-hanging fruit" in terms of converting courses to ZTC. Sustainability and long-term growth are now the priorities. Braddlee and VanScoy suggest that the easiest task is for librarians to help faculty find high-quality resources. They found that faculty have mixed views of other roles librarians might play, such as mentoring or developing policies, but they acknowledge this could change. ${ }^{17}$ At STCC, the outreach and OER librarian convenes the OER committee, assists faculty in finding and adapting OER, and participates in statewide initiatives. Identifying a role specifically with OER helps the library emphasize the importance of OER on campus.

Having a cohort or community of faculty colleagues can provide one ladder to success. Tiffini A. Travis, when looking at how best to initiate curricular changes, stated that the "team change agent model best fits in a higher education setting." ${ }^{18}$ And in a study of 11 educators who adopted OER, Danielle Paradis found that "community played a large role in the decision of most of the participants to engage with open textbooks or other forms of OER." 19 The STCC faculty who will teach new OER courses this year participated in a yearlong training to become OER liaisons. Going forward, they will be available to help other faculty with OER projects. This mentorship model is key to the library's strategy of increasing the use of OER.

Incentives are also important. The Centre for Educational Research and Innovation says that 
"institutions have to ask themselves what can be done to provide incentives for faculty to participate in an OER initiative." This could include adding an OER requirement to the tenure process or counting the successful use of OER as proof of excellence in teaching. ${ }^{20}$ In terms of funding, the NNLM grant that STCC received has now ended, so we are unable to keep the stipend model that helped to grow our program. We are looking into other options, but have no direct leads as of yet.

As we continue to strategize ways to promote OER courses, an effort is underway to get OER indicators added to the course schedule, which will help students search for OER classes online. Another goal is to create an entire ZTC degree using current OER offerings, which would allow students to get a general studies degree without buying any textbooks.

Many factors affect individual and institutional decisions to adopt OER or to allocate resources in support of comprehensive change. We hope that future research will look into whether the experience of rapidly transitioning many in-person classes to be taught online during the current pandemic moves the needle more in favor of OER across the country.

\section{OER during COVID-19}

Certainly, OER are not the only option for supporting online or remote learning, but, as Lindsey Gumb points out, life during the pandemic has "shown more than ever why true OER have significant value in ensuring students have access to their learning materials, because they are free and have licenses that allow for reuse and retention without limitation."21 Also, Willa Tavernier notes that many publishers are now allowing open access to scientific articles about COVID-19. This new reality is "a proof of concept for what is possible" and "it becomes possible to question whether [we] will find it acceptable for publishers to continue to put paywalls around research" in the future. ${ }^{22}$

The experience of promoting OER at STCC during the COVID-19 crisis has been mixed so far. Most classes in the fall 2020 semester, including all arts and humanities classes, were held online. Only a few lab sections were on campus, with most employees working remotely until at least Thanksgiving. The realities of the pandemic emphasize the importance of low-cost materials for our students, since many of them are now out of work or have additional expenses with their children being home from school. On the other hand, faculty are also stressed. Some of them believe that adopting OER may create additional work in their conversion to remote learning.

In 2019 the STCC Library launched a repository at OERCommons.org to house syllabi and other materials created by STCC faculty. We are working on adding the newest courses to the site so faculty can use their colleagues' work for inspiration. Unfortunately, budget cuts and staff layoffs due to the pandemic resulted in the school losing at least three OER courses. The cuts have also led to uncertainty among staff and faculty, which may undermine their motivation to try something new. The library's activities are complemented by the Center for Online and Digital Learning, which has been conducting trainings and workshops for faculty moving courses online. In their sessions, they encourage investigating OER as part of the process.

Overall, we are trying our best to be sensitive to the concerns and stresses of the faculty while also considering the increased needs of the school's struggling students. At STCC, as elsewhere, this is a very challenging time.

\section{Summary and conclusion}

Advantages of OER include affordability and equity, flexibility, and easy digital access. The OER initiative at STCC has made progress through collaboration, outreach, funding, and mentorship with a dedicated librarian in the role of facilitator. A recent survey of students confirmed an unmet need for more ZTC courses at STCC. A yearlong fellowship funded the development of several new ZTC courses and created a cohort of faculty OER liaisons who can assist others in the future.

Collegiality and community, ongoing outreach, a go-to point person, and multiple levels of institutional support are all important aspects of a sustainable OER initiative. Currently, the end of a grantfunded fellowship and the challenges posed by COVID-related budget cuts are curtailing the growth of OER adoption at our institution, although efforts continue to make lower-cost materials available for our students.

\section{Notes}

1. Malcolm Brown, etal.2020EDUCAUSEHorizon Report, Teaching and Learning Edition (Lou- 
isville, CO: EDUCAUSE, 2020), https://library. educause.edu/resources/2020/3/2020-educause -horizon-report-teaching-and-learning-edition.

2. Patricia A. Marshall, Robert J. Awkward, and Stephanie Teixeira, "Massachusetts Is an OER Exemplar," The New England Journal of Higher Education, November 5, 2019, https://nebhe.org /journal/massachusetts-is-an-oer-exemplar/.

3. "OER State Policy Tracker," SPARC, accessed May 11, 2020, https://sparcopen.org /our-work/state-policy-tracking/.

4. Dr Braddlee and Amy Vanscoy, "Bridging the Chasm: Faculty Support Roles for Academic Librarians in the Adoption of Open Educational Resources," College \& Research Libraries 80, no. 4 (May 2019): 426-449, https://doi.org/10.5860 /crl.80.4.426.

5. Scott Kersey, "The Effectiveness of Open Educational Resources in College Calculus. A Quantitative Study," Open Praxis 11, no. 2 (AprilJune 2019): 185-93, https://doi.org/10.5944 /openpraxis.11.2.935; Hong Lin, “Teaching and Learning without a Textbook: Undergraduate Student Perceptions of Open Educational Resources," International Review of Research in Open and Distributed Learning 20, no. 3: 1-18; Santhosh Mathew and Upasana Kashyap, "Impact of OER Materials on Students' Academic Performance in an Undergraduate Astronomy Course," Journal of STEM Education 20, no. 1 (April-September 2019): 46-49; Amy T.Nusbaum, Carrie Cuttler, and Samantha Swindell, "Open Educational Resources as a Tool for Educational Equity: Evidence From an Introductory Psychology Class" Frontiers in Education 4:152 (January 2020), https://doi. org/10.3389/feduc.2019.00152.

6. Phillip J. Grimaldi, Debshila Basu Mallick, Andrew E. Waters, Richard G. Baraniuk, "Do Open Educational Resources Improve Student Learning? Implications of the Access Hypothesis," PLoS ONE, March 6, 2019, https://doi. org/10.1371/journal.pone.0212508.

7. "Federal Pell Grant Recipients Academic Years 2015-2018," Springfield Technical Community College, accessed February 3, 2020, https://www.stcc.edu/media/departments /institutional-research/Federal-Pell-Grant -Recipients-AY-2015---2018.pdf.

8. “Open Educational Resources Strategic
Framework," STCC Library, March 2017, https:// libguides.stcc.edu/OER/framework.

9. For detailed survey responses and further discussion, see: Chelsea Contrada and Kathryn Good-Schiff, 2019 Student Textbook Survey Results and Findings (Springfield, MA: STCC Library, April 2020), https://libguides.stcc.edu/ ld.php?content_id=54131862.

10. Nicholas B. Colvard, C. Edward Watson, and H. Hyojin Park, "The Impact of Open Educational Resources on Various Student Success Metrics," The International Journal of Teaching and Learning in Higher Education 30, no. 2 (2018): 262-76, http://www.isetl.org/ijtlhe/pdf/ IJTLHE3386.pdf.

11. Phillip J. Grimaldi, et al., "Do Open Educational Resources Improve Student Learning? Implications of the Access Hypothesis."

12. Lindsey Gumb, "What's 'Open' During COVID-19? In Global Pandemic, OER and Open Access Matter More than Ever," The New England Journal of Higher Education, April 14, 2020, https://nebhe.org/journal/whats-openduring-covid-19-in-global-pandemic-oer-andopen-access-matter-more-than-ever/; Hong Lin, "Teaching and Learning without a Textbook: Undergraduate Student Perceptions of Open Educational Resources."

13. For more about the flexibility that OER allow for, see: David Wiley, "Defining the 'Open' in Open Content and Open Educational Resources," accessed May 13, 2020, http:// opencontent.org/definition/.

14. Florida Virtual Campus, 2018 Florida Student Textbook \& Course Materials Survey, (Tallahassee, FL: 2019), https://dlss.flvc.org /documents/210036/1314923/2018+Student + Textbook+and + Course + Materials + Survey $+\mathrm{R}$ eport+--+FINAL+VERSION+--+20190308. pdf/07478d85-89c2-3742-209a-9cc5df8cd7ea; Lindsay Renee Murphy and David Rose, "Are Private Universities Exempt from Student Concerns About Textbook Costs? A Survey of Students at American University."

15. Rebecca Griffiths, Jessica Mislevy, Sam Wang, Linda Shear, Alexandra Ball, Donna Desrochers, OER at Scale: The Academic and Economic Outcomes of Achieving the Dream's OER Degree Initiative, p. ES-1 (Menlo Park, CA: SRI Interna- 
tional, 2020), https://www.achievingthedream. org/resource/17993/oer-at-scale-the-academic -and-economic-outcomes-of-achieving-the -dream-s-oer-degree-initiative.

16. Penny Beile, Aimee deNoyelles, and John Raible, "Analysis of an Open Textbook Adoption in an American History Course: Impact on Student Academic Outcomes and Behaviors," College \& Research Libraries 81, no. 4 (May 2020), 721-763, https://doi.org/10.5860/crl.81.4.721.

17. Dr Braddlee and Amy Vanscoy, "Bridging the Chasm: Faculty Support Roles for Academic Librarians in the Adoption of Open Educational Resources."

18. Tiffini A. Travis, "Librarians as Agents of Change: Working with Curriculum Committees Using Change Agency Theory," New Directions for Teaching \& Learning, 2008, no. 114 (Summer 2008): 17-33, https://doi.org/10.1002/tl.314.

19. Danielle Paradis, "Chapter Five: Re- flection, Conclusion, and Recommendations," An Examination of the Lived Experience of Eleven Educators Who Have Implemented Open Textbooks in Their Teaching (Colwood, British Columbia: Royal Roads University, May 2014), https://paradisopentextbooks.pressbooks.com/chapter/chapterfive-reflection-conclusion-and-recommendations/.

20. Centre for Educational Research and Innovation, Giving Knowledge for Free: The Emergence of Open Educational Resources, p. 125, Organisation for Economic Co-Operation and Development, 2007, http://www.oecd.org /education/ceri/38654317.pdf.

21. Lindsey Gumb, "What's 'Open’ During COVID-19? In Global Pandemic, OER and Open Access Matter More than Ever."

22. Willa Tavernier, "COVID-19 Demonstrates the Value of Open Access," College \& Research Libraries News, 81 no. 5 (2020): 226-230, https://doi.org/10.5860/crln.81.5.226. ح

("YAIR," continued from page 131)

For small private institutions, especially those with a low STEM profile, I recommend that you focus on student work, including student journals and ETDs. I also suggest including informal material, such as book talks, podcasts, and conference proceedings. Institutional repositories need not focus strictly on peer-reviewed scholarly work. They should showcase and promote intellectual output that reflects the talent and culture of its institution. Both prospective faculty and students can then use the material to evaluate and understand the institution, its values, and its spirit.

\section{Notes}

1. "Pathways to Our Future: The Strategic Plan for Yeshiva University 2016-2020," Yeshiva University, accessed February 6, 2020, https://www.yu.edu/sites/default/files/inline-files /_PathwaysToOurFuture_2017_0.pdf.

2. See https://repository.yu.edu /RichardSteiner.

3. Aaron Tay, "Rethinking Institutional Repositories," Online Searcher 2.41 (2017): 10-15,
https://www.academia.edu/33979115/Rethinking _Institutional_Repositories.

4. "Yeshiva Academic Institutional Repository: User's Guide," accessed February 6, 2020, https:// library.yu.edu/RepositoryGuidehttps://library.yu.edu/ RepositoryGuide.

5. See Richard Poynder's interview especially concerning IRs for electronic theses and dissertations (ETDs). Richard Poynder, "Series Interview with Richard Poynder," interview by Jayashree Rajagopalan, October 23, 2015, https:// www.editage.com/insights/series/interview-with -richard-poynder.

6. See Texas A\&M Retrospective Theses.

7. Catalog of University Authors, https:// repository.yu.edu/handle/20.500.12202/3946.

8. "Macalester Faculty Observe: Students Who Publish Understand Scholarship More Deeply," bepress.com, April 11, 2017, https://www.bepress. $\mathrm{com} /$ macalester-faculty-observe-students-publishunderstand-scholarship-deeply/.

9. https://v2.sherpa.ac.uk/romeo/.

10. Tay, "Rethinking Institutional repositories," "Inconsistencies and Poor User Experience." 2 